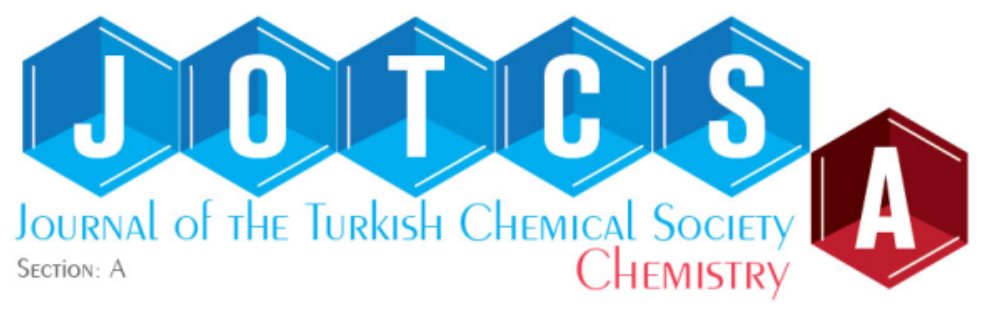

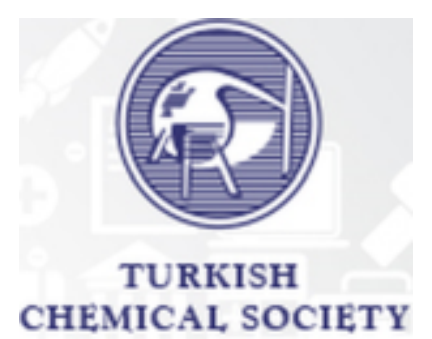

CHEMICAL SOCIETY

\title{
Ethnobotany, Phytochemistry, Ethnopharmacology, and Toxicity of Euclea divinorum Hiern (Ebenaceae): A Review
}

\author{
Timothy Omara ${ }^{1,2 *}$ (D), Bernard Otieno Sadia ${ }^{1,2}$ iD, Immaculate Mbabazi,2 (D), \\ Augastine Okwir ${ }^{3}$
}
${ }^{1}$ Department of Chemistry and Biochemistry, School of Sciences and Aerospace Studies, Moi University, P.O. Box 3900-30100, Eldoret, Kenya.
${ }^{2}$ Africa Centre of Excellence II in Phytochemicals, Textile and Renewable Energy (ACE II PTRE), Moi University, P.O. Box 3900-30100, Eldoret, Kenya.
${ }^{3}$ Department of Chemistry, Faculty of Science, Kyambogo University, P. O. Box 1, Kampala, Uganda.

\begin{abstract}
Euclea divinorum Hiern (Ebenaceae) is a medicinal plant widely used in Yemen, Eastern and Southern Africa in traditional phytotherapy. This review was an attempt to compile a comprehensive report on its ethnomedicinal uses, phytochemicals, pharmacological activities, and toxicity, lending credence to the use of its various parts in herbal medicine. The literature encountered indicated that herbal formularies from different parts of Euclea divinorum (E. divinorum) are majorly used for traditional treatment of odontological, dermatological, respiratory, reproductive, and gastrointestinal ailments. At least 18 compounds have been isolated and characterized in extracts of $E$. divinorum, while 31 others have been identified in the crude extracts analyzed by GC-MS. Extracts, as well as isolated compounds from $E$. divinorum stem, stem barks, leaves, and roots, showed renoprotective, antiproliferative, antinociceptive, contractile, proteolytic, diuretic, antiprotozoal, anti-giardial, antioxidant, anti-inflammatory, antimicrobial, molluscicidal, and insecticidal activities. Further research is warranted to explore other pharmacological properties such as antisnake venom, aphrodisiac, antidiabetic, analgesic, and antimycobacterial activities and the responsible bioactive compounds in the different parts of $E$. divinorum claimed in herbal medicine. The composition and bioactivities of essential oils from this species also warrant further studies.
\end{abstract}

Keywords: Euclea divinorum, chewing sticks, naphthoquinone, triterpene, flavonoid.

Submitted: September 29, 2021. Accepted: February 24, 2022 .

Cite this: Omara T, Sadia B, Mbabazi I, Okwir A. Ethnobotany, Phytochemistry, Ethnopharmacology and Toxicity of Euclea divinorum Hiern (Ebenaceae): A Review. JOTCSA. 2022;9(2):355-72.

DOI: https://doi.org/10.18596/jotcsa.1001676.

*Corresponding author: prof.timo2018@gmail.com, prof.timo2018@mu.ac.ke, Tel: +254-742777349.

\section{INTRODUCTION}

Natural products from plants, animals, fungi, bacteria, and other biomaterials are recognized globally as veritable sources of the most known and yet-to-be discovered therapeutically effective allopathic drugs $(1,2)$. This is due to their structural diversity, which is crucial in tackling the current multi-drug resistance crisis vis-à-vis synthetic molecules, which are tedious to produce or possess side effects owing to their lack of specificity (3). Plants are by far the most used organisms for their supposed medicinal potential since time immemorial. They are used by more than $80 \%$ of the global population for the management of various ailments and conditions (4). This is evident in developing countries where there are shrinking health services, poverty and the aphorism that herbal medicines are more effective, safe, accessible, affordable, and culturally acceptable (57). Thus, intensive ethnobotanical, phytochemical, and pharmacological investigations have been carried out on medicinal flora worldwide in the past decades. 
The medicinal plant Euclea divinorum Hiern is a deciduous shrub from the persimmon or ebony (Ebenaceae) family which, consists of over 768 shrubs and trees placed in four major genera: Diospyros L., Euclea L., Lissocarpa L., and Royena L. $(8,9)$. The family name Ebenaceae is derived from the genus Ebenus, first published by Otto Kuntze in 1891 , implying that it is a later homonym of Ebenus L. genus in the Fabaceae family (10). The genus Euclea has a genesis of its name from the Greek word "eukleia", meaning "of good report" or "famous", which alludes to the fine ebony-like wood of some species in it (11). The species $E$. divinorum was first named by William Phillip Hiern for its popular use by diviners (sangomas) in some parts of Africa, hence the epithet "divinorum" (11-13). The shrub grows to about $6 \mathrm{~m}$ tall, with a muchbranched grey-green crown, and is commonly found in Eastern and Southern Africa (14-17). It has simple leaves (Figure 1) which are coriaceous and lanceolate, with wavy margins, sub-opposite or alternate, usually $3.5-9 \mathrm{~cm}$ long and $1-2.5 \mathrm{~cm}$ wide (11). The flowers are cup-shaped, creamy and characteristically small. Usually, the male and female flowers occur on separate trees. The berries (fruits) are round, single-seeded, and fleshy (12). The common synonyms of this species include $E$. racemosa Murr. subsp. schimperi ( $E$. schimperi $A$. DC.) (18), E. lanceolata sensu Hiern (13), $E$. huillensis Gürke, E. katangensis De Wild., $E$. keniensis R.E.Fr., E. kiwuensis Gürke and $E$. stuhlmannii Gürke and E. stuhlmannii Gürke (19).

E. divinorum inhabits grasslands, thickets, open bushlands, and margins of evergreen forests at altitudes of up to $2700 \mathrm{~m}$ (19). In some areas, it is considered a fast establishing, unpalatable, and fireresistant invasive species (20-22). The species is distributed from Sudan through Ethiopia, Zimbabwe, Namibia, Botswana, Swaziland, and South Africa (23-31). It has also been reported in the Soqotra Archipelago of Yemen (27, 32-35). E. divinorum has been considerably researched. However, information on this species remains largely scattered in electronic reports. This review was an attempt to provide a comprehensive overview of its ethnobotany, phytochemistry, ethnopharmacology, and toxicity. The present review sheds light on and lends credence to the use of $E$. divinorum plant organs in the traditional management of various ailments claimed in folklore.

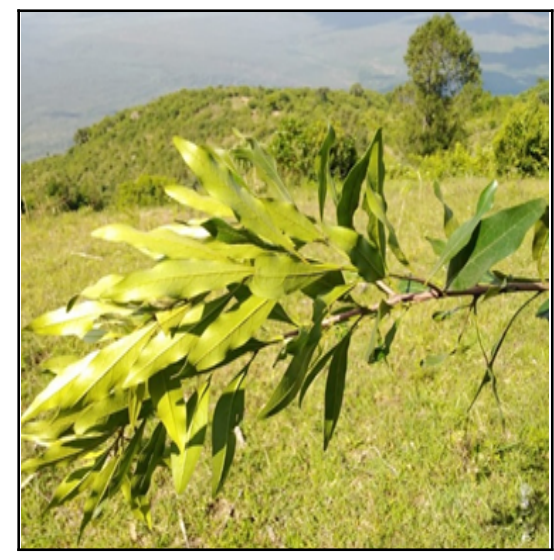

(a)

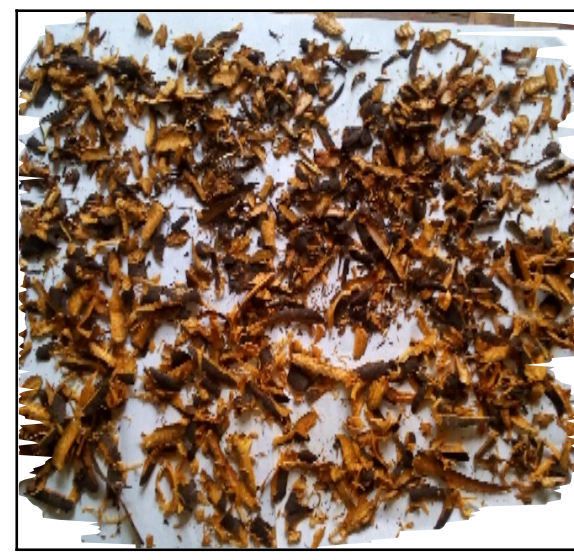

(b)

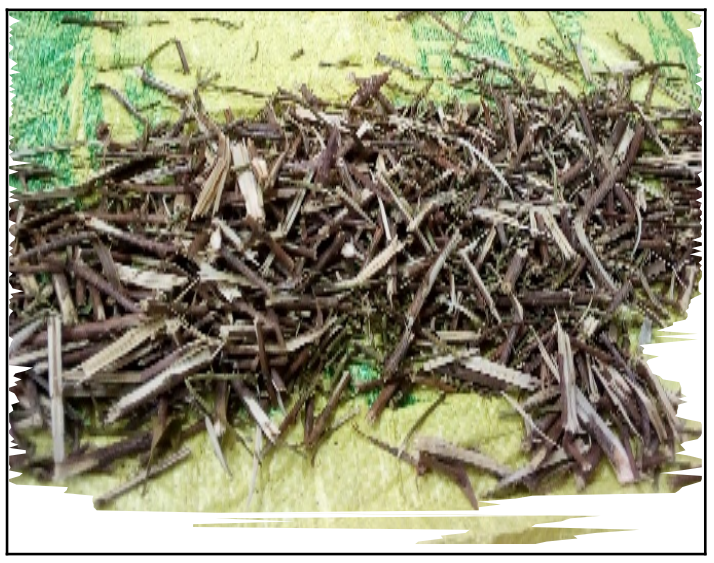

(c)

Figure 1: Different parts of E. divinorum used in traditional medicine (a) leaves, (b) root bark, and (c) twigs. The photos were taken by Immaculate Mbabazi from Elgeythatakwet, Kenya. 


\section{METHODOLOGY}

This study is a non-systematic review that analyzed scholarly reports and peer-reviewed articles published on $E$. divinorum in open literature dated up to September 2021. The reviewed literature was retrieved electronically from PubMed, Science Direct, Scopus, Google Scholar, Springer Link, Taylor and Francis Online, Wiley Online Library, and Web of Science Core Collection. A further general search was performed using Google search engine to find other documents, reports, botanical databases and theses from various university repositories. The search keywords used singly and in combination were Euclea divinorum, Euclea divinorum, $E$. divinorum, magic guarri, and diamond-leaved Euclea. The reports were screened for their relevance and inclusion in the review. Ethnobotany (traditional medicinal uses), nonmedicinal or commercial uses, phytochemistry, ethnopharmacology, cytotoxicity, and genotoxicity profile data of $E$. divinorum were collected to highlight gaps for future studies.

\section{RESULTS AND DISCUSSION}

Non-Medicinal (Textile, Cosmeceutical, and Economic) Uses of $E$. divinorum

The roots, leaves, and other parts of $E$. divinorum showed high tannin contents $(36,37)$, which constitutes an inherent defense mechanism against herbivory of species in the Euclea genus (10). They are therefore widely used in Tanzania, Zimbabwe, Kenya, Botswana, and Yemen as purple ink, black dye for mats, wool, for tanning leather, basket ware, and other textiles, especially when a mordant of iron-rich mud is used after dyeing $(11,38-42)$.
The roots are usually chewed to impart a red color to the mouth and lips $(23,34,35,39)$. In Ethiopia, Zimbabwe, South Africa, Tanzania, and Kenya, the whole fruits (black sweet berries) are eaten and used for making beverages (juice and beer), though it also provides firewood, shade, amenity and timber $(18,19,39,43-48)$. The leaves are burnt to produce plant ash as an edible salt (49).

The leaves, fruits, dried or fresh parts (e.g. stems) are used for making corrals (kraal), house ceilings, building poles, spoons, grain stores, tool handles, walking sticks, and forage for cattle and camels in Ethiopia, Kenya, Tanzania, and Yemen $(18,19,34,35,45,50)$. The branches are used in Kenya (51) and South Western Ethiopia (52) to purify drinking water in which they are added and left to soak in the water for several hours. They are also used to treat milk, to improve digestibility and palatability, or to preserve it $(42,53)$. In some parts of Africa, the small branches of this species are hung at the doorsteps of houses as "a good luck charm" (11). Furthermore, its tolerance of soils containing high levels of heavy metals (particularly arsenic) has made it an indicator of gold reefs or deposits (11) and has since been utilized in the recovery of gold mine pit wastes.

\section{Ethnomedicinal Uses of E. divinorum}

The medicinal relevance of a plant is often reflected by its high frequency of use and citation in ethnobotanical surveys (54). E. divinorum is called magic guarri, diamond leaf, toothbrush tree, or diamond leaved Euclea in English (12). As shown in Table 1, E. divinorum has many local names by which it is known whithin local communities across Africa and Yemen.

Table 1: Local names of E. divinorum used across Africa and Yemen.

\begin{tabular}{|c|c|c|}
\hline Folk name (vernacular name) & Country & Reference(s) \\
\hline $\begin{array}{l}\text { Nhlangula (Xitsonga), mutangule (Venda), Motlhakola (Tswana), } \\
\text { umhlangula (Zulu), towerghwarrie (Afrikaans), mohlakola (Northern } \\
\text { Sotho), umhlanqula, umdlelanyamatane (Swati), nhlanqula (Tsonqa) }\end{array}$ & $\begin{array}{c}\text { South Africa, } \\
\text { Lesotho }\end{array}$ & $(11,12,55)$ \\
\hline Umdlelanyamatane (siSwati) & Swaziland & $(31)$ \\
\hline $\begin{array}{c}\text { Kapcheptuin, Olkinyie, Uswet (Markweta), mdaa, mdala, msirisha } \\
\text { (Swahili), msanganetu (Batemi) olkinyei (Maa), akado, ochol, } \\
\text { Ochondradoho (Luo), Ikimusi (Kuria), Mukinyai, Kikuthi/Mukinyei } \\
\text { (Kamba), Kumuchanjasi (Luhya) }\end{array}$ & Kenya & $(23,48,56-64)$ \\
\hline Omudime (Oshiwambo) & Namibia & $(39,65)$ \\
\hline Umushikiri (Kinyarwanda) & Rwanda & $(66)$ \\
\hline $\begin{array}{c}\text { Omusikizi (Lunyankore), Emuc (Langi), Kasalagala/Muda (Lusoga), } \\
\text { nsikizi (Luganda) }\end{array}$ & Uganda & $(12,67-71)$ \\
\hline Mi'eessa (Oromiffa), Dedeho (Amharic) & Ethiopia & $(30,72-74)$ \\
\hline Mdaa (Swahili), Msekela & Tanzania & $(75)$ \\
\hline Mushangura (Shona), Umtshekesane (Ndebele) & Zimbabwe & $(12,13)$ \\
\hline Munyansyabweli & Zambia & $(76)$ \\
\hline
\end{tabular}

Several formulations containing different parts of $E$. divinorum singly or in combination with other plant parts are used for the treatment of both human and animal ailments. The range of treated diseases includes malignancies, central nervous system, odontological, dermatological, respiratory, gastrointestinal, reproductive, venereal, and general ailments or infections (Table 2; Figure 2). The most used parts are the roots and the root bark, probably because of their ability to accumulate therapeutic 
phytochemicals, which are responsible for the treatment of various ailments (77). Generative and/or reproductive structures such as flowers, fruits, and seeds, which are also reputed to accumulate phytochemicals, are less commonly used, probably because the plant blossoms once a year (from August to December) (11). As a result of the use of such structures, plant organs for medication would be limited throughout the year.

Other than the foregoing medicinal uses, $E$. divinorum is also used in various cultural practices. For example, the plant is given to candidates during initiation by the Sebei of Uganda or used in important "koresek" Sebei ceremonies (rituals of purification). Among the Sabaot of Kenya, the leaves are used as sleeping mats for initiates during their period of seclusion (18). Its root powder is applied onto incisions to remove spells in Uganda (78). The leaves and roots of this species are also used for love affairs (75). In Ethiopia, E. divinorum along with other trees such as Cordia africana Lam., Ehretia cymosa (Thonn.) and Maesa lanceolata Forssk. are symbolically revered as Haaganaa trees (trees ordained by mystical powers) and are used in rituals of avoiding inauspicious omen, idiotism, homicide case resolution and mythical power expression (72). In South Africa, E. divinorum is used in magical practices (79).

Table 2: Ethnomedicinal uses of different parts of $E$. divinorum based on encountered literature.

\begin{tabular}{ccccc}
\hline Ailment(s) & Part(s) & Preparation or & Country & Reference \\
treated/uses & used & administration & (s) \\
\hline
\end{tabular}

1. General

infections/conditions

Malaria

Root bark, roots, leaves

Blood cleanser/purifier

Fruits, roots

Arthritis

Roots

Used as a cathartic to induce purgation

Bleeding

Stroke

Chest pains, headache, internal body swellings called "kati"

Various ailments and for good health (as a tonic or an invigorant)

\section{Odonatological diseases/dental hygiene}

Used as a mouth antiseptic/disinfectant, clean and whiten the teeth

(toothbrushes/misawk), treat gum bleeding,

toothache, tooth cavity

\section{Reproductive \\ system diseases and conditions}

Venereal

diseases/infections

(syphilis, gonorrhoea,
Roots, bark, fruits

Bark, seeds, roots, leaves

Roots

Roots

Stem bark, roots, fruits

Branches

(twigs), root bark, roots

Roots, leaves

Root extract with those of Carissa edulis (Forsk.) Vahl and Carica papaya L. taken. Decoction may be taken directly

Usually followed by a cup of strong tea. Soup made from bark, fruits and roots may also be taken

Applied topically on fresh bleeding wounds

\section{Decoction/infusion taken}

Decoction prepared with Croton megalocarpus roots taken

Bark or with roots are boiled with meat soup and taken. Fruits chewed. Added to children's milk

Chewed roots/ powdered root barks, mixed with little water and salt, and inserted into the tooth cavity/for toothache. Roots are used for brushing teeth for dental hygiene. Dried root/bark powder rubbed to clean teeth
Decoction. May also be used with roots of Hagenia abyssinica and Grewia ferruginea Chewed and saliva swallowed

Powder applied to incisions

Roots are chewed after gentle warming over an open flame. Ethiopia
Kenya, Zambia,

$(30,44,80-$

Ethiopia

Kenya, Yemen

Uganda

Kenya, South

Africa ,

Tanzania

$(19,48,64,8$ $4,86,87)$

Namibia South Africa, Yemen Kenya, Tanzania Kenya, South Africa

Kenya, Uganda, Tanzania

$(15,52,62,6$ $3,86,90-$

Kenya,

Yemen, Uganda,

Zimbabwe,

South Africa,

$(18,19,32,3$

Tanzania $52,84,87,9$

3)

$(30,61,76,9$ 4-97) 


\begin{tabular}{|c|c|c|c|c|}
\hline $\begin{array}{l}\text { Ailment(s) } \\
\text { treated/uses }\end{array}$ & $\begin{array}{l}\text { Part(s) } \\
\text { used }\end{array}$ & $\begin{array}{l}\text { Preparation or } \\
\text { administration }\end{array}$ & Country & $\begin{array}{c}\text { Reference } \\
\text { (s) }\end{array}$ \\
\hline \multicolumn{5}{|l|}{$\begin{array}{l}\text { genital herpes, oral } \\
\text { candidiasis, abscesses) }\end{array}$} \\
\hline Infertility & Roots & Decoction taken & Kenya & $(61)$ \\
\hline Miscarriage & Roots & Decoction drunk & Uganda & $(78)$ \\
\hline $\begin{array}{l}\text { Managing delayed and } \\
\text { protracted labour, post- } \\
\text { partum haemorrhage, } \\
\text { and removing things } \\
\text { retained after birth }\end{array}$ & $\begin{array}{l}\text { Leaves, } \\
\text { roots }\end{array}$ & Chewed & Kenya & $(56)$ \\
\hline $\begin{array}{l}\text { Cervical cancer, } \\
\text { prophylaxis of cancer }\end{array}$ & $\begin{array}{l}\text { Leaves, } \\
\text { fruits }\end{array}$ & $\begin{array}{c}\text { Infusion drunk, fruits chewed as } \\
\text { a prophylaxis }\end{array}$ & Uganda & $(63,67,98)$ \\
\hline Salpingitis & Roots & Powder drunk as tea & Uganda & $(78)$ \\
\hline $\begin{array}{l}\text { 4. Dermatological } \\
\text { conditions } \\
\text { Skin infections (rash, } \\
\text { abscesses, disorders, } \\
\text { irritations, ringworms, } \\
\text { pimples, chickenpox, } \\
\text { inflammation, eczema) }\end{array}$ & $\begin{array}{l}\text { Leaves, root } \\
\text { bark, roots, } \\
\text { fruits }\end{array}$ & $\begin{array}{c}\text { Applied topically (add leaf/root } \\
\text { powder to jelly and smear or } \\
\text { bark powder to water and } \\
\text { apply) or boiled to take a bath. } \\
\text { Fruits chewed }\end{array}$ & $\begin{array}{l}\text { South Africa, } \\
\text { Yemen, } \\
\text { Uganda, } \\
\text { Ethiopia, } \\
\text { Kenya }\end{array}$ & $\begin{array}{c}(32,34,35,5 \\
5,63,69,70, \\
79,97,99)\end{array}$ \\
\hline Leprosy, scabies & Leaves & Not reported & Ethiopia & $(30)$ \\
\hline Snakebites & Roots, bark & $\begin{array}{c}\text { Crushed \& applied on incision } \\
\text { made on the bite area, used } \\
\text { with dry roots of Tragia } \\
\text { brevipes, Gardenia volkensii and } \\
\text { Plectranthus barbatus }\end{array}$ & $\begin{array}{l}\text { Kenya, } \\
\text { Uganda }\end{array}$ & $\begin{array}{c}(78,100- \\
102)\end{array}$ \\
\hline Jaundice & Roots & Decoction drunk & $\begin{array}{l}\text { Uganda, } \\
\text { Tanzania }\end{array}$ & $(75,78)$ \\
\hline $\begin{array}{c}\text { Wound healing, } \\
\text { antiseptic, disinfectant, } \\
\text { cicatrizing against } \\
\text { infection, used as a } \\
\text { maturative }\end{array}$ & Roots & Not reported & South Africa & $(103)$ \\
\hline Rabies & Leaves & Not reported & Ethiopia & $(30)$ \\
\hline \multicolumn{5}{|l|}{$\begin{array}{l}\text { 5. Respiratory } \\
\text { ailments }\end{array}$} \\
\hline $\begin{array}{l}\text { Tuberculosis, cough, } \\
\text { respiratory disorders }\end{array}$ & $\begin{array}{l}\text { Roots, } \\
\text { fruits, } \\
\text { leaves }\end{array}$ & Chewed & $\begin{array}{l}\text { Uganda, } \\
\text { Kenya }\end{array}$ & $(63,68,85)$ \\
\hline Pneumonia & Roots, bark & $\begin{array}{l}\text { Decoction prepared with Croton } \\
\text { megalocarpus roots taken }\end{array}$ & $\begin{array}{c}\text { Kenya, South } \\
\text { Africa }\end{array}$ & $\begin{array}{c}(19,84,86,8 \\
7)\end{array}$ \\
\hline \multicolumn{5}{|l|}{$\begin{array}{l}\text { 6. Gastrointestinal } \\
\text { infections and } \\
\text { metabolic disorders } \\
\text { and ailments } \\
\text { Ulcers }\end{array}$} \\
\hline & Roots & Decoction taken & Swaziland & $(31)$ \\
\hline Abdominal upsets & Fruits & Chewed & Kenya & $(63)$ \\
\hline Amebiasis, tapeworm & Leaves & Not reported & Ethiopia & (30) \\
\hline $\begin{array}{l}\text { Constipation, } \\
\text { anthelminthic, } \\
\text { abdominal pain }\end{array}$ & $\begin{array}{l}\text { Roots, } \\
\text { leaves }\end{array}$ & Not reported & $\begin{array}{c}\text { Kenya, South } \\
\text { Africa, } \\
\text { Ethiopia }\end{array}$ & $\begin{array}{c}(58,85,87,9 \\
7,104)\end{array}$ \\
\hline
\end{tabular}




\begin{tabular}{|c|c|c|c|c|}
\hline $\begin{array}{c}\text { Ailment(s) } \\
\text { treated/uses }\end{array}$ & $\begin{array}{l}\text { Part(s) } \\
\text { used }\end{array}$ & $\begin{array}{l}\text { Preparation or } \\
\text { administration }\end{array}$ & Country & $\begin{array}{c}\text { Reference } \\
\text { (s) }\end{array}$ \\
\hline $\begin{array}{l}\text { Stomach pain, } \\
\text { stomachache, }\end{array}$ & $\begin{array}{l}\text { Roots, bark, } \\
\text { leaves }\end{array}$ & Decoction taken & $\begin{array}{c}\text { South Africa, } \\
\text { Kenya }\end{array}$ & $(84,87)$ \\
\hline Appetizer & Roots, bark & $\begin{array}{c}\text { Root decoction. Bark added to } \\
\text { soup with Rhamnus prinoides } \\
\text { and taken }\end{array}$ & Kenya & $(18,48)$ \\
\hline Diabetes & Root bark & Decoction taken & Kenya & (57) \\
\hline $\begin{array}{l}\text { Kidney } \\
\text { infection/problems, } \\
\text { hepatitis }\end{array}$ & $\begin{array}{l}\text { Stem bark, } \\
\text { root bark }\end{array}$ & Crushed and used & Ethiopia & $(73,97)$ \\
\hline $\begin{array}{l}\text { 7. Ethnoveterinary } \\
\text { uses } \\
\text { Used as an analgesic }\end{array}$ & Stem bark & Decoction given & Kenya & $(60)$ \\
\hline $\begin{array}{c}\text { General veterinary } \\
\text { diseases }\end{array}$ & Fruits & Decoction given & Kenya & (105) \\
\hline
\end{tabular}

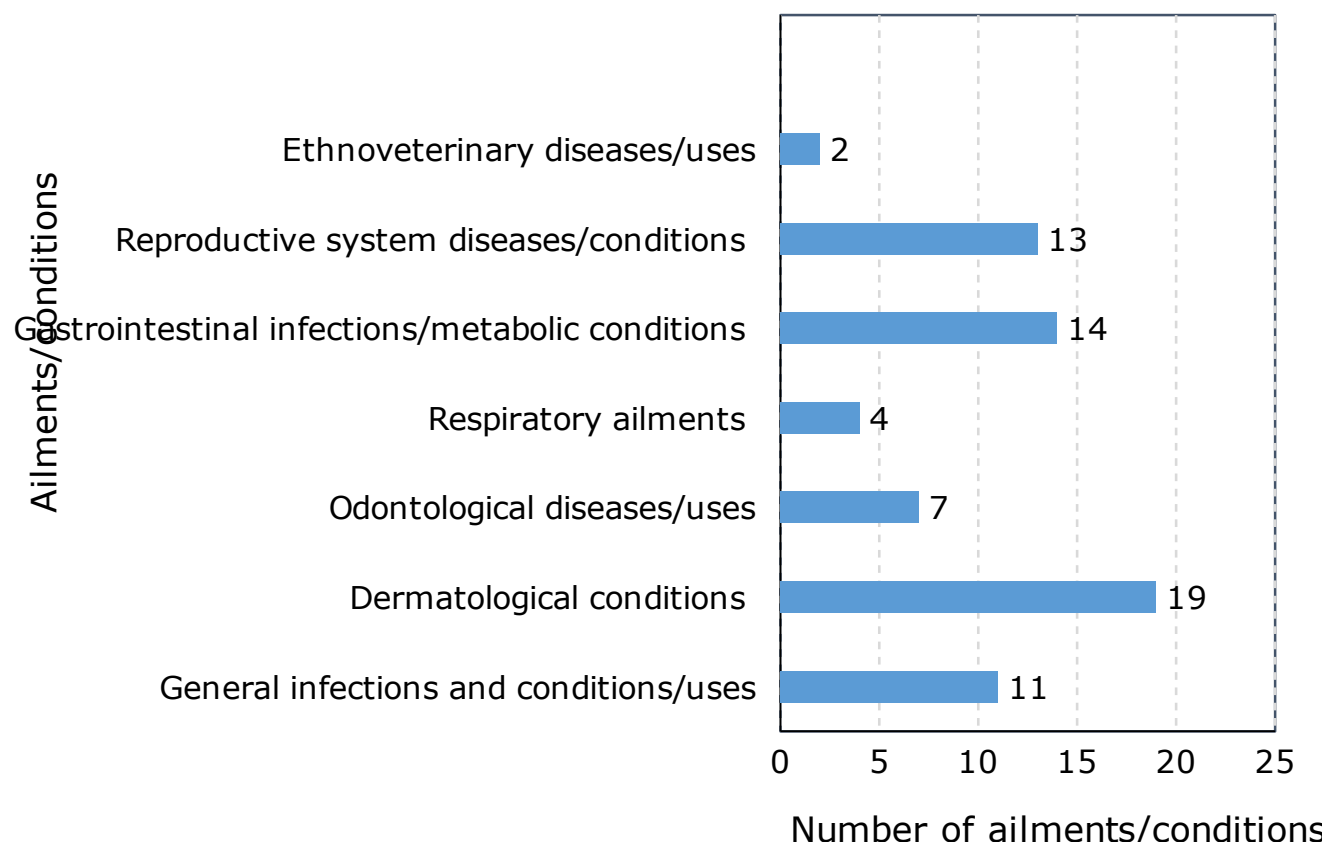

Figure 2: Major groups of ailments and conditions treated using preparations of E. divinorum.

\section{Phytochemistry of E. divinorum}

Phytochemical investigations on $E$. divinorum extracts have been conducted. Conventional phytochemical screening of organic and aqueous extracts of $E$. divinorum have been carried out. Tannins, saponins, flavonoids, terpenes, alkaloids, steroids, terpenoids, and reducing compounds were identified as the major secondary metabolites (Table 3).

For quantification of phytochemicals, an earlier study reported total phenolic and water-soluble phenolic contents of $122.7 \mathrm{mg} / \mathrm{g}$ and $77.1 \mathrm{mg} / \mathrm{g}$, respectively and tannin by protein precipitation of $94 \mathrm{mg} / \mathrm{g}$ from the bark of $E$. divinorum (62).
Mbabazi et al. (2021) quantified the polyphenol content of n-hexane, ethanol and dichloromethane (DCM) extracts of $E$. divinorum leaves, stems and root barks (106). The total phenolic and total flavonoid contents were the highest in ethanol, followed by DCM and then n-hexane extracts. The order of abundance recorded was root barks > tender stems > leaves (Table 4). However, the total flavonoid content was the highest in ethanol extract followed by $n$-hexane and lastly DCM extract. The high polyphenols content is hypothesized to be the reason for the inhibition of growth of teeth-attacking bacteria by the parts of this species used in dental hygiene and controlling dental caries (106). 
Table 3. Secondary metabolites reported in E. divinorum extracts.

\begin{tabular}{|c|c|c|c|}
\hline Part(s) used & $\begin{array}{l}\text { Solvent(s) } \\
\text { used }\end{array}$ & Metabolites detected & Author(s) \\
\hline $\begin{array}{l}\text { Leaves, stem, } \\
\text { root bark }\end{array}$ & $\begin{array}{c}\text { n-hexane, DCM, } \\
\text { ethanol }\end{array}$ & $\begin{array}{c}\text { Alkaloids, flavonoids, cardiac glycosides, phenols, } \\
\text { saponins, quinones, steroids, tannins, terpenes and } \\
\text { volatile oils }\end{array}$ & $(106)$ \\
\hline Root bark & Ethyl acetate & Alkaloids, flavonoids, saponins, tannins, terpenoids & $(25)$ \\
\hline Stem, roots & DCM & $\begin{array}{c}\text { Alkaloids, flavonoids, glycosides, phenolics, saponins, } \\
\text { tannins, terpenes }\end{array}$ & $(107)$ \\
\hline Roots & Ethyl acetate & Alkaloids, flavonoids, steroids and terpenes & $(27)$ \\
\hline Roots & $\begin{array}{c}\text { Methanol, } \\
\text { distilled water }\end{array}$ & $\begin{array}{c}\text { Flavonoids, saponins, tannins, terpenoids, steroids, } \\
\text { cardiac glycosides }\end{array}$ & $(108)$ \\
\hline $\begin{array}{l}\text { Roots, root } \\
\text { bark }\end{array}$ & $\begin{array}{l}\text { Methanol, ether, } \\
\text { distilled water }\end{array}$ & $\begin{array}{l}\text { Tannins, saponins, alkaloids, steroids, terpenoids, } \\
\text { reducing compounds, flavonoids, steroids, terpenoids, } \\
\text { flavonoid aglycones }\end{array}$ & $(90)$ \\
\hline $\begin{array}{l}\text { Leaves, roots, } \\
\text { stems }\end{array}$ & DCM : methanol & $\begin{array}{c}\text { Anthraquinones, alkaloids, saponins, tannins, } \\
\text { polyphenols, terpenoids }\end{array}$ & $(109)$ \\
\hline Roots & DCM & Triterpenoids, amino acids, resins, tannins & $(110)$ \\
\hline Roots & Methanol & Phenolic acids, tannins & $(111)$ \\
\hline Leaves, fruits & Methanol & $\begin{array}{c}\text { Polyphenols, tannins, sterol/triterpenes, glycosides, } \\
\text { carbohydrates }\end{array}$ & $(30)$ \\
\hline
\end{tabular}

Table 4: Total polyphenolic content of the E. divinorum parts.

\begin{tabular}{ccccc}
\hline Polyphenol & $\begin{array}{c}\text { Plant } \\
\text { organ }\end{array}$ & $\begin{array}{c}\text { n-hexane } \\
\text { extract }\end{array}$ & $\begin{array}{c}\text { *DCM } \\
\text { extract }\end{array}$ & $\begin{array}{c}\text { Ethanol } \\
\text { extract }\end{array}$ \\
\hline Total phenolic & Leaves & 299.0 & 1190.0 & 1516.0 \\
content & Tender stems & 231.0 & 828.0 & 2800.0 \\
Total & Root barks & 472.0 & 1569.0 & 3105.0 \\
flavonoid & Leaves & 84.3 & 23.4 & 63.10 \\
content & Tender stems & 55.6 & 27.6 & 81.60 \\
\hline
\end{tabular}

Pioneering elucidative studies of bioactive compounds in E. Divinorum, just like in other Euclea species, led to the identification of naphthoquinones, triterpenes and flavonoids. For example, 7-methyljuglone, mamegakinone, diospyrin, and isodiospyrin were reported in the root extract of $E$. divinorum, but stems and green fruits extracts had no napthoquinones (See Figure 3; 112). Cruz-Costa et al. (113) reported the presence of 7-methyljuglone, diospyrin, 2methylnaphthazarin, betulin, diosindigo $A$, and lupeol in petroleum ether extract of $E$. divinorum roots (Figure 3). Flavonoids: (2R:3R)aromadendrin-3-O- $\beta$-L-arabinopyranoside, catechin, quercitrin, and myricitrin were later characterized in the ethanolic extracts of $E$. divinorum aerial parts (14).

Phytochemical characterization of chloroform extract of $E$. divinorum root bark led to the identification of naphthoquinones, triterpenoids and flavonoids viz: 7-methyljuglone, isodiospryrin, betulin, lupeol, catechin, 3- $\beta$-(5-hydroxyferuloly)lup-20-(30)-ene, shinalene, and lupene (114). Further, the bioactive compounds in the leaves of $E$. divinorum were characterized and two new compounds: Euclenal $A$ or 8-hydroxy-3-methoxy-1-naphthaldehyde and Euclenal B or 4-hydroxy-3,8-dimethoxy-1naphthaldehyde were identified (52). A new naphthalene derivative: 8-hydroxy-6-methoxy-1naphthaldehyde or eucleanal was identified in ethyl acetate extract of $E$. divinorum leaves (115) (Figure 3). Recently, Kilonzo et al. identified Y-sitosterol , germanicol, and oxacycloheptadec-8-en-2-one, (8Z) in ethyl acetate extract of $E$. divinorum root bark by GC-MS (Table 5). In another report, Mbabazi et al. (2021) identified 28 compounds GC-MS in n-hexane and dichloromethane extracts of $E$. divinorum leaves, tender stems, and root barks (Table 5) (106). 
<smiles>Cc1cc(O)c2c(c1)C(=O)C=CC2=O</smiles>

(1)<smiles>Cc1cc(O)c2c(c1)C(=O)C=C(C1=CC(=O)c3cc(C)cc(O)c3C1=O)C2=O</smiles>

(2)<smiles>CCc1cc(O)c2c(c1)C(=O)C(c1c(C)cc3c(c1O)C(=O)C=CC3=O)=CC2=O</smiles>

(3)<smiles>Cc1cc2c(c(O)c1-c1c(C)cc(O)c3c1C(=O)C=CC3=O)C(=O)C=CC2=O</smiles>

(4)<smiles>CC1=CC(=O)c2c(O)ccc(O)c2C1=O</smiles>

(5)

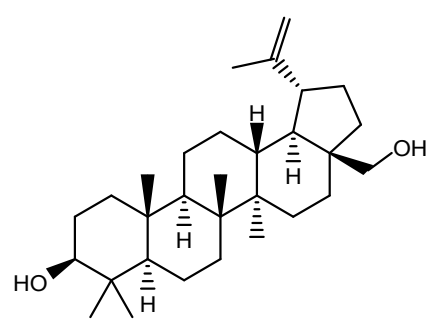

(6)<smiles>[R]C1CC(O)C2C([R])C1C(O)C(O)C2C</smiles>

(7)

(8)

(9)<smiles>Oc1cc(O)c2c(c1)OC(c1ccc(O)c(O)c1)C(O)C2</smiles>

(10)<smiles>[R2]Oc1cc(-c2oc3cc(O)cc(O)c3c(=O)c2OCC[R4]([R])([H])O)cc(O)c1O</smiles>

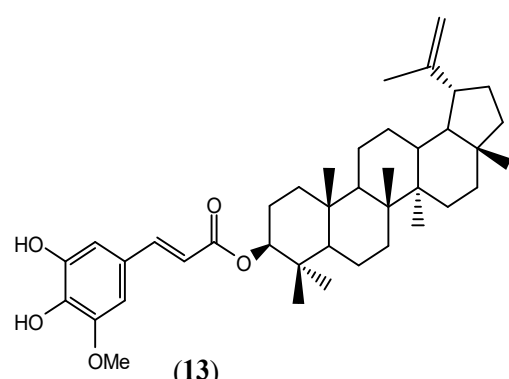<smiles>C=C(C)[C@H]1CC[C@]2(C)CC[C@]3(C)[C@H](CC[C@H]4[C@@]3(C)CC[C@]3(C)C(C)(C)CCC[C@]43C)[C@H]12</smiles>

(15)<smiles>COc1cc(C=O)c2c(O)cccc2c1</smiles>

(16)<smiles>COc1cc(C=O)c2c(OC)cccc2c1O</smiles>

(17)

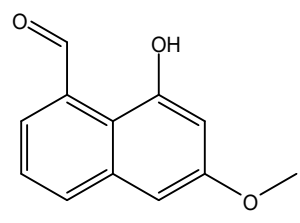

(18)

Figure 3: Structures of some compounds isolated from extracts of E. divinorum. 
Table 5: Compounds identified in extracts of E. divinorum by GC-MS.

\begin{tabular}{|c|c|c|}
\hline Part & Extractant & Compounds identified \\
\hline Root bark & Ethyl acetate & $\begin{array}{c}\text { Y-sitosterol } \\
\text { Germanicol } \\
\text { Oxacycloheptadec-8-en-2-one, (8Z) } \\
\text { 1-Methyl-2-Pyrrolidinone } \\
\text { Eicosane }\end{array}$ \\
\hline \multirow[t]{6}{*}{ Leaves } & n-hexane & Tetratriacontane \\
\hline & & 2-Hydroxy-2-methyl-8,8-diphenyl-octa-5,7-dien-3-one \\
\hline & & Eicosane \\
\hline & & Tetratriacontane \\
\hline & & Palmitic acid \\
\hline & & Ethyl palmitate \\
\hline \multirow{9}{*}{$\begin{array}{l}\text { Tender } \\
\text { stems }\end{array}$} & n-hovano & $\begin{array}{c}\text { Ethyl-9,12-octadecadienoate } \\
\text { Ethyl 9a-linolenate }\end{array}$ \\
\hline & n-llexalle & 4,8,12,16-Tetramethylheptadecan-4-olide \\
\hline & & Tetracosane \\
\hline & & 9-Tricosene \\
\hline & & Heptacosanol \\
\hline & & $\begin{array}{l}\text { Hexatriacontane } \\
\text { Heneicosane }\end{array}$ \\
\hline & & Eicosane \\
\hline & & Tetratriacontane \\
\hline & & Hexatriacontane \\
\hline \multirow[t]{7}{*}{ Root bark } & n-hexane & 1,4-Naphthoquinone \\
\hline & & 7-Ethoxycoumarin \\
\hline & & 4-Vinyl guaiacol \\
\hline & & $\begin{array}{l}\text { Squalene } \\
\text { Eicosane }\end{array}$ \\
\hline & & Tetratriacontane \\
\hline & & Ethyl palmitate \\
\hline & & Heptacosanol \\
\hline \multirow[t]{4}{*}{ Leaves } & DCM & Squalene \\
\hline & & Octadecanal \\
\hline & & Cis, cis, cis-7,10,13-Hexadecatrienal \\
\hline & & $\begin{array}{c}\text { Tetradecyl acrylate } \\
\text { Octacosanal } \\
\text { Eicosane }\end{array}$ \\
\hline \multirow{3}{*}{$\begin{array}{l}\text { Tender } \\
\text { stems }\end{array}$} & & Tetratriacontane \\
\hline & DCM & $\begin{array}{c}\text { Hexatriacontane } \\
\text { Tetratetracontane } \\
\text { Y-Tocopherol }\end{array}$ \\
\hline & & 2-Ethylhexyl acrylate \\
\hline \multirow{3}{*}{ Root bark } & $\mathrm{DCM}$ & 2,6,11-Trimethyldodecane \\
\hline & & 3,4-Methylenedioxybenzylacetone \\
\hline & & 9-Hexadecen-1-ol \\
\hline
\end{tabular}




\section{Pharmacological Profile of E. divinorum}

Different extracts and isolated compounds from $E$. divinorum have been investigated and reported to have antiproliferative (antitumor), antinociceptive, anti-giardial, renoprotective, antiprotozoal, molluscicidal, insecticidal, contractile, proteolytic, diuretic, antioxidant, anti-inflammatory, and antimicrobial activities.

\section{Antiproliferative and antitumor activity}

Some isolated compounds from $E$. divinorum $(\mathbf{1}, \mathbf{4}$, $6,8,10,13-15)$ were assessed for their antitumor potential against BC-1 (human breast cancer), Lu-1 (human lung cancer), HT (human fibrosarcoma), KB (human nasopharyngeal carcinoma), KB-V (vinblastine resistant $\mathrm{KB}$ evaluated in the presence and absence of vinblastine), Me-1 (human melanoma), P-388 (murine lymphocytic leukemia), A431 (human epidermoid carcinoma), Col-2 (human colon cancer), LNCaP (human prostate cancer), ZR75-1 (human breast cancer) and U373 (human glioblastoma) cell lines (114). The authors reported that compounds 1 and 13 exhibited strong cytotoxicity, while the rest of the compounds were not cytotoxic. Interestingly, $\mathbf{1}$ was cytotoxic to all the cancer cells and the most intense responses were registered for $\mathrm{KB}, \mathrm{P}-388$, LNCaP, ZR-75-1 and U373 cells at concentrations of $4.8,0.1,0.8,2.2$ and $2.7 \mu \mathrm{g} / \mathrm{mL}$, respectively. On the other hand, 13 was highly selective and showed cytotoxicity only against two cancer cells (P-388 and ZR-75-1) at 2.1 and $4.2 \mu \mathrm{g} / \mathrm{mL}$, respectively. The antiproliferative activity of the crude extracts of this species has not been reported.

\section{Renoprotective activity}

The potential of crude methanolic extract, and methanolic and aqueous fractions of $E$. divinorum leaves to reduce gentamicin-induced nephrotoxicity in rats was investigated (74). The authors reported that the extract and fractions reversed gentamicinmediated alterations by decreasing tubular necrosis, serum and oxidant markers, and increment in antioxidant molecules. The renoprotective effect decreased with an increase in crude extract dosage whereas maximum protection was afforded at 100 $\mathrm{mg} / \mathrm{kg}$ of the methanolic fraction for in vivo and in vitro studies. The authors postulated that the renoprotective effect of the extract and fractions could be due to the antioxidant potentials of their moderately polar phytochemicals (74).

\section{Antimicrobial activity}

Kirui et al. (2015) indicated that the aqueous extract of the whole plant of $E$. divinorum retarded the growth of bacterial colonies in water (51). In another research, ethanolic extracts of $E$. divinorum leaves and barks were assessed for their inhibitory activity against some selected oral pathogens (116). The extracts did not inhibit the growth of Candida albicans ( $C$. albicans) unlike Streptococcus mutans where the of the inhibition zone diameters (ZOI) were $6.0 \mathrm{~mm}$ and $2.4 \mathrm{~mm}$ at $2 \mathrm{mg}$ and $3 \mathrm{mg}$ of extracts per disk, respectively. The reported minimum inhibitory concentration (MIC) ranged from 3.1 to $25.0 \mu \mathrm{g} / \mathrm{mL}$ against Actinomyces naes/undii, Actinomyces israelii, Streptococcus mutans, Actinobacillus actinomycetemcomitans, and Porphyromonus gingivalis.

The ethanolic extracts of leaves, stem barks, and roots of $E$. divinorum showed antibacterial activity against Escherichia coli (E. coli), Staphylococcus aureus (S. aureus), Campylobacter jejuni, Streptococcus pyogenes, and Shigella sonnei with ZOI varying from $10 \mathrm{~mm}$ to $14 \mathrm{~mm}$ (117). Aqueous extracts exerted bacteriostatic activity against $E$. coli, S. aureus, Shigella sonnei and Campylobacter jejuni with the same range of ZOI, but did not inhibit the growth of Streptococcus pyogenes, Bacillus cereus, Pseudomonas aeruginosa, and Salmonella typhi. The root extract only inhibited the growth of Streptococcus pyogenes with a ZOI of 13 $\mathrm{mm}$ (117). Later, Geyid et al. (2005) found that methanolic extract of $E$. divinorum leaves retarded the growth of $C$. albicans and Cryptococcus neoformans ( $C$. neoformans) when tested at 4000 $\mu \mathrm{g} / \mathrm{mL}$ (30). Mining (48) reported ZOI of 17.6, 10.6, $6.0,12.6$ and $6.6 \mathrm{~mm}$ for DCM extract of $E$. divinorum leaves against $E$. coli, $S$. aureus, Pseudomonas aeruginosa, Bacillus subtilis, and $C$. albicans.

In another investigation (111), the root methanolic extract of $E$. divinorum exhibited antimicrobial activity against multidrug-resistant Staphylococcus strains (S. epidermidis 847, S. haemolyticus 535, and $S$. aureus North German Epidemic strain with ZOI of $24 \mathrm{~mm}, 16 \mathrm{~mm}$, and $26 \mathrm{~mm}$, respectively), S. aureus, Bacillus subtilis, Micrococuss flavus, $E$. coli, Pseudomonas aeruginosa and Candida maltosa with a ZOI of $24 \mathrm{~mm}, 12 \mathrm{~mm}, 18 \mathrm{~mm}, 11 \mathrm{~mm}, 15$ $\mathrm{mm}$, and $10 \mathrm{~mm}$. Another team (118) evaluated the antifungal activities of some Venda plant extracts against $C$. albicans, Candida krusei, and $C$. neoformans isolated from South African AIDS patients. The n-hexane extract of $E$. divinorum leaves was more active against $C$. neoformans with a ZOI of $8 \mathrm{~mm}$ at $10 \mu \mathrm{L}$. No bioactivity was observed against the other fungi.

The aqueous and DCM/methanol extracts of $E$. divinorum roots had no antimicrobial activity against E. Coli, while DCM extract had a ZOI of $10.30 \mathrm{~mm}$ (110). In the same study, DCM extract had ZOI of $10.75 \mathrm{~mm}$ and $10.00 \mathrm{~mm}$ against Streptococus aureus and Lactobacillus acidophilus, respectively. The DCM/methanol extracts had ZOI of $9.13 \mathrm{~mm}$, $10.80 \mathrm{~mm}$ and $6.70 \mathrm{~mm}$ while aqueous extracts had no inhibitory activity. In another study, crude root extracts of $E$. divinorum showed ZOI of $9.00 \mathrm{~mm}$ and $13.00 \mathrm{~mm}$ for Streptococcus mutans and Streptococcus sanguinis, with MICs of $1,250 \mu \mathrm{g} / \mathrm{mL}$ and 2,500 $\mu \mathrm{g} / \mathrm{mL}$, respectively (109). 
Ethanolic extracts of $E$. divinorum stem bark exhibited anti-mycoplasmal activity against Mycoplasma mycoides subsp. mycoides (Afadé, B 237, Gladysdale, PG1 and V5), Mycoplasma mycoides subsp. capri (Y-Goat, 95010, G1313.94, M-18 and G1255/94) and Mycoplasma capricolum subsp. capricolum (Mcc) $6443-90$ with MIC of 0.500 $\mathrm{mg} / \mathrm{mL}, 0.417 \mathrm{mg} / \mathrm{mL}$ and $0.500 \mathrm{mg} / \mathrm{mL}$ against the strains, respectively (60). In another investigation, the antibacterial screening indicated that ethyl acetate extract of $E$. divinorum root was effective in inhibiting $E$. coli $(\mathrm{ZOI}=17 \mathrm{~mm}$ ) while $S$. aureus was resistant to the extract (ZOI $=9 \mathrm{~mm}$; same as that of ethanol used as negative control) (27). Methanolic, methanol : DCM and aqueous extracts of $E$. divinorum were reported to have no inhibitory or bactericidal effects against Methicillin-Resistant S.aureus, S.aureus, S.mutans and C.albicans (119).

Another report indicated that DCM extract of $E$. divinorum roots excerted the highest antifungal activity (ZOI $=30 \mathrm{~mm}$ ) against Trichophyton mentagrophytes. Its antifungal activity was comparable to that of the ethyl acetate (ZOI $=20$ $\mathrm{mm}$ ) and methanolic (ZOI $=25 \mathrm{~mm}$ ) extracts against the six tested fungal strains: Absidia corymbifera, Aspergillus fumigatus, Candida krusei, Microsporum gypseum, Mucor species and Trichophyton mentagrophytes with ZOI ranging between $15 \mathrm{~mm}$ and $20 \mathrm{~mm}$ (34). Acetonic and aqueous extracts of $E$. divinorum roots were indicated to excert antifungal activity against $C$. albicans, Microsporum canis and Trichophyton rubrum with average MIC of 0.23 to $0.47 \mathrm{mg} / \mathrm{mL}$ (79). Kilonzo et al. (25) reported that petroleum ether, ethyl acetate and aqueous extracts of $E$. divinorum leaves, stem bark and root bark showed antimicorbial activity against $S$. aureus (MIC = 0.718 to $>25 \mathrm{mg} / \mathrm{mL}$ ), Klebsiella pneumoniae (MIC $=0.718>25 \mathrm{mg} / \mathrm{mL})$, E. coli $($ MIC $=0.718>25$ $\mathrm{mg} / \mathrm{mL}$ ), Salmonella typhi (MIC $=0.718$ to $>25$ $\mathrm{mg} / \mathrm{mL}$ ), C. albicans (MIC $=0.718$ to $>25 \mathrm{mg} / \mathrm{mL}$ ), and $C$. neoformans ( $\mathrm{MIC}=0.718$ to $>25 \mathrm{mg} / \mathrm{mL}$ ).

Mbabazi et al. (2020) in a comparative study investigated the antimicrobial activity of $E$. divinorum leaves, tender stems and root bark and a formulated herbal toothpaste from its extracts against oral pathogens (120). The plant materials were extracted sequentially by maceration with dichloromethane, n-hexane and ethanol. The root barks ethanolic extract was the most active with a MIC of $25 \mu \mathrm{g} / \mathrm{mL}, 50 \mu \mathrm{g} / \mathrm{mL}, 25 \mu \mathrm{g} / \mathrm{mL}$ and 25 $\mu \mathrm{g} / \mathrm{mL}$ against Streptococcus pyogenes, $S$. aureus, $E$. coli and C. albicans. Herbal toothpaste formulated with the ethanolic extract of $E$. divinorum root barks had the highest activity against the tested microorganisms (ZOI = from $7.67 \mathrm{~mm}$ to 22.67 $\mathrm{mm}$ ) compared to Colgate herbal toothpaste formulated with fluoride as the active ingredient (ZOI $=5.00 \mathrm{~mm}$ to $16.33 \mathrm{~mm}$ ).
Anti-giardial and antiprotozoal activities

To validate the gastrointestinal use of $E$. divinorum in traditional medicine, a pioneering investigation concluded that methanolic extracts of its roots and barks did not cause death of Giardia lamblia trophozoites at $500 \mathrm{ppm}$ and $1000 \mathrm{ppm}$ (121). The methanolic extract of $E$. divinorum roots showed antiprotozoal (antiplasmodial, antileishmanial and antitrypanosomal) activities with $\mathrm{IC}_{50}$ of $37.5 \pm 4.7$ $\mu \mathrm{g} / \mathrm{mL},>64.0 \pm 0.0 \mu \mathrm{g} / \mathrm{mL}, 22.5 \pm 4.7 \mu \mathrm{g} / \mathrm{mL}$ and $33.1 \pm 5.3 \mu \mathrm{g} / \mathrm{mL}$ against Plasmodium falciparum K1 strain, Leishmania infantum, Trypanosoma cruzi and Trypanosoma brucei Squib-427 strain (122). The antiplasmodial results were corroborated by another report from Kenya in which methanolic extract of $E$. divinorum root barks had antiplasmodial activity with IC $_{50}$ of $6.9 \mu \mathrm{g} / \mathrm{mL}$ and $12.4 \mu \mathrm{g} / \mathrm{mL}$ against D6 and W2 P.falciparum strains, respectively (123).

Antinociceptive, antioxidant and anti-inflammatory activities

Mwonjoria et al. (2018) reported that DCM extracts of $E$. divinorum stems and roots showed significant antinociceptive effects in the second phase of formalin-induced nociception when tested at doses of $50 \mathrm{mg}$ and $100 \mathrm{mg}$ on Wistar rats (107). Feyissa et al. (2013) reported that the maximum percentage inhibitions of 1,1-diphenyl-2-picrylhydrazyl (DPPH) at $2000 \mathrm{mg} / \mathrm{mL}$ by the methanolic fraction, aqueous fraction and crude methanolic extract of $E$. divinorum leaves were $82.5 \%, 74.5 \%$ and $62.5 \%$, respectively (74). In another report, $\mathrm{IC}_{50}$ between 8.30 and $>1000 \mu \mathrm{g} / \mathrm{mL}$ were reported on $E$. divinorum leaf extracts in DPPH radical and nitric oxide antioxidant assays (124). In antiinflammatory activity assay, the recorded Cyclooxygenase-2 (COX-2) inhibition at $10 \mu \mathrm{g} / \mathrm{mL}$ was $71.12 \%$. In a recent report, the $\mathrm{IC}_{50}$ values of DCM, ethyl acetate, and methanolic (direct and sequential) extracts of $E$. divinorum obtained in DPPH radical scavenging activity were $690.5 \mu \mathrm{g} / \mathrm{mL}$, $680.8 \mu \mathrm{g} / \mathrm{mL}, \quad 550.0 \mu \mathrm{g} / \mathrm{mL}$, and $225.0 \mu \mathrm{g} / \mathrm{mL}$, respectively (34).

\section{Contractile, proteolytic and diuretic activities}

The folkloric use of $E$. divinorum to induce or augment labour, manage protracted labour and post-partum haemorrhage was validated through investigation of the contractile activity of its aqueous and ethanolic root barks extracts (125). The extracts stimulated uterine tissue contractility and augmented its response to oxytocin. The increase in uterine contractions as a percentage relative to negative controls was particularly significant in pregnant rabbit tissues in the presence of oxytocin, where increments of up to $245 \%$ were observed.

Aqueous extract of $E$. divinorum twigs inhibited $50 \%$ of proteolytic activity against Bacteroides gingivalis, Bacteriodes intermedius, and Treponema denticola at concentrations ranging from $10 \mu \mathrm{g} / \mathrm{mL}$ up to 200 
$\mu \mathrm{g} / \mathrm{mL}$ (126). Another report (127) indicated that aqueous extracts of $E$. divinorum and Rhus natalensis had high inhibitory effects on the proteolytic activities of Porphyromonas gingivalis, Bacteriodes intermedius and Treponema denticola, which indicates that the extracts could reduce the virulence of these periodontophathic bacteria as well as the rate of dental plaque formation.

Further, the assessment of the diuretic potential of methanolic and aqueous extracts of $E$. divinorum roots in Sprague Dawley rats revealed that methanolic extract produced significant diuresis at $200 \mathrm{mg} / \mathrm{kg}$ and $400 \mathrm{mg} / \mathrm{kg}$ while aqueous extract produced significant diuresis at all tested doses (108).

\section{Molluscicidal and insecticidal activities}

E. divinorum methanolic extract had molluscicidal activity against $B$. glabrata in 48 hours at concentrations under $500 \mu \mathrm{g} / \mathrm{mL}$ (128). Examining the insecticidal activity of $E$. divinorum to verify its use in the management of storage pests indicated that its $n$-hexane and DCM leaf extracts caused $35 \%$ and $60 \%$ mortality when tested against bean weevils (Acanthoscelides obtectus) at 1000 ppm (48). However, the essential oils have not been tested for its insecticidal potential.

\section{Adverse side effects, toxicity and genotoxicity profiles of $E$. divinorum extracts}

E. divinorum root extract is traditionally reported to have laxative effects which is counteracted by inclusion of half glass of Achyranthes aspera leaves and Ficus natalensis roots or barks (89). The petroleum ether/ethyl acetate $(1: 1)$ and methanolic extracts of $E$. divinorum roots were reported to be cytotoxic to human ECV-304 cells with IC $_{50}$ values of $11.6 \mu \mathrm{g} / \mathrm{mL}$ and $36.0 \mu \mathrm{g} / \mathrm{mL}$, respectively (32). Another study reported the $\mathrm{IC}_{50}$ value of $27.5 \pm 3.6$ $\mu \mathrm{g} / \mathrm{mL}$ for methanolic extract of $E$. divinorum roots against human lung fibroblast MRC-5 SV2 cells (122). Acute toxicity studies of methanolic extract of $E$. divinorum leaves indicated that it was safe when administered orally at $2000 \mathrm{mg} / \mathrm{kg}$ (74). Even after a period of 72 hours, the animals tolerated the administered dose, with no appreciable changes in behaviour (motor activity, diarrhoea, breathing, alertness, restlessness, convulsions, coma and appearance). Since no mortality was recorded within 14 days, the lethal dose ( $\left.L D_{50}\right)$ was indicated to be more than $2000 \mathrm{mg} / \mathrm{kg}$ (74).

The methanolic, methanol: DCM and aqueous extracts of $E$. divinorum were reported to be noncytotoxic (119). Al-Fatimi (2019), reported the low cytotoxicity ( $\mathrm{IC}_{50}$ values of 240.0 to $900.5 \mu \mathrm{g} / \mathrm{mL}$ ) of DCM, ethanolic and methanolic extracts of $E$. divinorum roots from Yemen against human amniotic epithelial cells line (FL-cells) (34). nhexane and DCM extracts of leaves showed lethality against brine shrimp with LD $_{50}$ of 952.0 and 689.9 ppm (48). These reports indicate that some extracts of this species are potentially cytotoxic.

An investigation examining the genotoxic activity in human peripheral blood lymphocytes of some South African plants (129) reported that DCM extract of $E$. divinorum roots induced DNA damage, which were however lower than that of the positive control (1 $\mathrm{mM}$ potassium bichromate). Another report, carried out by the same team (130), indicated that DCM extract rather than the methanolic extract of $E$. divinorum roots was toxic in the Ames test.

\section{CONCLUSION}

Euclea divinorum possesses a long history of use in herbal medicine in Africa and Yemen. Significant strides have been made in the past decades in isolating, elucidating, and evaluating the bioactive compounds as well as pharmacological activities of this species. Some identified compounds have been reported to have remarkable in vitro and in vivo bioactivity. Thus, the folkloric claims of using this species in managing various ailments are credible, but further research is warranted to explore other pharmacological properties such as antisnake venom, aphrodisiac, antidiabetic, analgesic, and antimycobacterial activities, the responsible compounds in the different parts of $E$. divinorum and their mechanisms of action. More toxicity studies are needed to demonstrate sufficient proof for human safety when employing $E$. divinorum extracts and/or isolated components. Further research into the content and bioactivities of essential oils derived from this plant is warranted. Clinical trials using $E$. divinorum extracts and isolated substances are also necessary. Indigenous groups should be encouraged to prioritize its protection due to its broad ethnomedicinal, economic, and cultural value.

\section{ABBREVIATIONS}

C. albicans: Candida albicans; C. neoformans: Cryptococcus neoformans; DCM: Dichloromethane; E. coli: Escherichia coli; E. divinorum: Euclea divinorum; MIC: Minimum Inhibitory Concentration; S. aureus: Staphylococcus aureus; ZOI: Zone inhibition diameter.

\section{CONFLICT OF INTEREST}

The authors declare that there is no conflict of interest regarding the publication of this paper.

\section{ACKNOWLEDGEMENTS}

The authors are grateful to the World Bank and the Inter-University Council of East Africa (IUCEA) for the scholarship awarded to Immaculate Mbabazi through the Centre of Excellence II in Phytochemicals, Textile and Renewable Energy (ACE II PTRE) at Moi University, Kenya, that prompted this review. 


\section{REFERENCES}

1. Amit Koparde A, Chandrashekar Doijad R, Shripal Magdum C. Natural Products in Drug Discovery. In: Perveen S, Al-Taweel A, editors. Pharmacognosy Medicinal Plants [Internet]. IntechOpen; 2019 [cited 2022 Feb 26]. $\leq$ URL $>$.

2. Omara T, Kiprop AK, Ramkat RC, Cherutoi J, Kagoya S, Moraa Nyangena D, et al. Medicinal Plants Used in Traditional Management of Cancer in Uganda: A Review of Ethnobotanical Surveys, Phytochemistry, and Anticancer Studies. EvidenceBased Complementary and Alternative Medicine. 2020 Mar 16;2020:1-26.

3. the International Natural Product Sciences Taskforce, Atanasov AG, Zotchev SB, Dirsch VM, Supuran CT. Natural products in drug discovery: advances and opportunities. Nat Rev Drug Discov. 2021 Mar;20(3):200-16.

4. WHO. WHO Global Report on Traditional and Complementary Medicine [Internet]. World Health Organization; 2021 [cited 2022 Feb 26]. $\leq$ URL $>$.

5. Schultz F, Anywar G, Wack B, Quave CL, Garbe LA. Ethnobotanical study of selected medicinal plants traditionally used in the rural Greater Mpigi region of Uganda. Journal of Ethnopharmacology. 2020 Jun;256:112742.

6. Tabuti JRS, Kukunda CB, Waako PJ. Medicinal plants used by traditional medicine practitioners in the treatment of tuberculosis and related ailments in Uganda. Journal of Ethnopharmacology. 2010 Jan;127(1):130-6.

7. Tugume P, Kakudidi EK, Buyinza M, Namaalwa J, Kamatenesi $M$, Mucunguzi $P$, et al. Ethnobotanical survey of medicinal plant species used by communities around Mabira Central Forest Reserve, Uganda. J Ethnobiology Ethnomedicine. 2016 Dec;12(1):5.

8. Anonymous. The Plant List. Ebenaceae [Internet]. The Plant List. 2021 [cited 2022 Feb 26]. <URL>.

9. Duangjai S, Wallnofer B, Samuel R, Munzinger J, Chase MW. Generic delimitation and relationships in Ebenaceae sensu lato: evidence from six plastid DNA regions. American Journal of Botany. 2006 Dec $1 ; 93(12): 1808-27$

10. Anonymous. Ebenaceae [Internet]. Ebenaceae. 2021. $\leq$ URL $>$.

11. Mothogoane M. Euclea divinorum Hiern [Internet]. Euclea divinorum Hiern. 2014. $\leq$ URL $>$.

12. Orwa C, Mutua A, Kindt $R$, Jamnadass $R$, Anthony S. Euclea divinorum Hiern (Ebenaceae)
[Internet]. Agroforestree Database:a tree reference and selection guide version $4.0 ; 2021$. $\leq U R L>$.

13. Hyde $M$, Wursten $B$, Ballings $P$, Coates Palgrave M. Flora of Zimbabwe: Species information: Euclea divinorum [Internet]. Zimbabweflora; 2021. <URL>.

14. Dagne $E$, Alemu M, Sterner O. Flavonoids from Euclea divinorum. Bull Chem Soc Eth. 1993;7(2):87-92.

15. Grinsven $M$, Parkipuny $M$, Johns $T$. Euclea divinorum (Ebenaceae) bark is a high-potential tanning material. Econonie Botany. 1999;53:220.

16. Smith TM, Goodman PS. Successional Dynamics in an Acacia Nilotica-Euclea Divinorum Savannah in Southern Africa. The Journal of Ecology. 1987 Sep;75(3):603.

17. Ivens G. The effects of arboricides on East African trees and shrubs IV. Tarchonanthus camphoratus L. and Euclea divinorum Hiern. Tropical Agriculture, Trinidad and Tobago. $1960 ; 37(2): 143-52$.

18. Maundu P. Traditional Food Plants of Kenya [Internet]. 1999. 288 p. $\leq U R L>$.

19. Lovett J, Ruffo C, Gereau R, Taplin J. Field Guide to the Moist Forest Trees of Tanzania [Internet]. The Society for Environmental Exploration, UK and the University of Dar es Salaam, Tanzania; 2005. $\leq$ URL $>$.

20. Wahungu GM, Gichohi NW, Onyango IA, Mureu LK, Kamaru D, Mutisya S, et al. Encroachment of open grasslands and Acacia drepanolobium Harms ex B.Y.Sjöstedt habitats by Euclea divinorum Hiern in Ol Pejeta Conservancy, Kenya. Afr J Ecol. 2013 Mar;51(1):130-8.

21. Mutunga Kavwele C. Time Series Monitoring of Bush Encroachment by \&lt;i\&gt; Euclea divinorum\&lt;/i\&gt; in Ol Pejeta Conservancy Laikipia, Kenya. IJNREM. 2017;2(5):85.

22. Parker JWPL, Parker AM. Herbicide Control of Euclea Divinorum - Preliminary Experiments. East African Agricultural and Forestry Journal. 1964 Oct;30(2):89-93.

23. Njuguna $P$. Euclea divinorum Hiern. Jansen $P$, Cardon D, editors. Wageningen, Netherlands: PROTA (Plant Resources of Tropical Africa / Ressources végétales de l'Afrique tropicale); 2005.

24. Anonymous. Euclea divinorum Hiern [Internet]. Board of Trustees of the Royal Botanic Gardens, Kew; 2021 [cited 2022 Feb 26]. <URL>.

25. Kilonzo M, Rubanza C, Richard U, Sangiwa G. Antimicrobial activities and phytochemical analysis 
of extracts from Ormocarpum trichocarpum (Taub.) and Euclea divinorum (Hiern) used as traditional medicine in Tanzania. Tanzania J Hlth Res. 2020 Sep $10 ; 21(2): 1-12$.

26. Hutchings A. Zulu medicinal plants: An inventory. [Internet]. University of Natal press; 1996. $\leq$ URL $>$.

27. Shumba L. Phytochemical composition and bacterial activity of Euclea divinorum [Internet] [Master of Science Thesis]. [Zimbabwe]: Bindura University of Science Education; 2018. $\leq$ URL>.

28. Mostert T, Bredenkamp G, Klopper H, Verwey C, Mostert R, Hahn N. Major vegetation types of the Soutpansberg Conservancy and the Blouberg Nature Reserve, South Africa: original research. Koedoe. $2008 ; 50(1): 32-48$.

29. Scogings P. Large herbivores and season independently affect woody stem circumference increment in a semi-arid African savanna. Plant Ecology. 2014;215:1433-43.

30. Geyid A, Abebe D, Debella A, Makonnen Z, Aberra $F$, Teka $F$, et al. Screening of some medicinal plants of Ethiopia for their anti-microbial properties and chemical profiles. Journal of Ethnopharmacology. 2005 Mar;97(3):421-7.

31. Amusan OOG, Dlamini PS, Msonthi JD, Makhubu LP. Some herbal remedies from Manzini region of Swaziland. Journal of Ethnopharmacology. 2002 Feb;79(1):109-12.

32. Al-Fatimi $M$, Friedrich $U$, Jenett-Siems $K$. Cytotoxicity of plants used in traditional medicine in Yemen. Fitoterapia. 2005 Jun;76(3-4):355-8.

33. Sharam G, Sinclair ARE, Turkington R. Establishment of Broad-leaved Thickets in Serengeti, Tanzania: The Influence of Fire, Browsers, Grass Competition, and Elephants1. Biotropica. 2006 Sep;38(5):599-605.

34. Al-Fatimi. Antifungal Activity of Euclea divinorum Root and Study of its Ethnobotany and Phytopharmacology. Processes. 2019 Oct $1 ; 7(10): 680$.

35. Miller G, Morris M. Ethnoflora of the Soqotra Archipelago. Edinburgh, UK: The Royal Botanic Garden; 2004.

36. Scogings $P$, Siko $S$, Taylor R. Calibration of a hand-held instrument for measuring condensed tannin concentration based on UV- and red-excited fluorescence. African Journal of Range \& Forage Science. 2014 Jan 2;31(1):55-8.

37. Hattas D, Julkunen-Tiitto $R$. The quantification of condensed tannins in African savanna tree species. Phytochemistry Letters. 2012 Jun; 5(2):329-34.

38. Manyim S, Kiprop AK, Mwasiagi JI, Achisa CM, Odero MP. Dyeing of cotton fabric with Euclea divinorum extract using response surface optimization method. RJTA [Internet]. 2021 May 5 [cited 2022 Feb 26]; <URL>.

39. Maroyi A. The Gathering and Consumption of Wild Edible Plants in Nhema Communal Area, Midlands Province, Zimbabwe. Ecology of Food and Nutrition. 2011 Nov;50(6):506-25.

40. China CR, Hilonga A, Nyandoro SS, Schroepfer M, Kanth SV, Meyer M, et al. Suitability of selected vegetable tannins traditionally used in leather making in Tanzania. Journal of Cleaner Production. 2020 Apr;251:119687.

41. Cunningham AB, Milton SJ. Effects of basketweaving industry on mokola palm and dye plants in northwestern Botswana. Econ Bot. 1987 Jul;41(3):386-402.

42. Cardon D. Dyes and Tannins. PROTA Foundation; 2005.

43. Bussmann RW, Gilbreath GG, Solio J, Lutura M, Lutuluo R, Kunguru $K$, et al. Plant use of the Maasai of Sekenani Valley, Maasai Mara, Kenya. J Ethnobiology Ethnomedicine. 2006 Dec;2(1):22.

44. Maundu P, Berger D, Ole Saitabau C, Nasieku J, Kipelian M, Mathenge $S$, et al. Ethnobotany of the Loita Maasai People and Plants Working Paper 8. 2001;

45. Gemedo-Dalle T, Maass BL, Isselstein J. Plant Biodiversity and Ethnobotany of Borana Pastoralists in Southern Oromia, Ethiopia. Economic Botany. 2005 Jan;59(1):43-65.

46. Mashile SP, Tshisikhawe MP, Masevhe NA. Indigenous fruit plants species of the Mapulana of Ehlanzeni district in Mpumalanga province, South Africa. South African Journal of Botany. 2019 May; $122: 180-3$.

47. Rampedi IT, Olivier J. Traditional Beverages Derived from Wild Food Plant Species in the Vhembe District, Limpopo Province in South Africa. Ecology of Food and Nutrition. 2013 May;52(3):203-22.

48. Mining J. Bioactive Metabolites Of Selected Kenyan Plants Used As Biopesticides Against Acanthoscelides obtectus in Bungoma District, Kenya [Internet] [Master of Science Thesis]. [Nairobi, Kenya]: Jomo Kenyatta University of Agriculture and Technology; 2008. $\leq U R L>$.

49. Euclea divinorum-Hiern [Internet]. Plants For A Future. 2021. $\leq$ URL $>$. 
50. Habte $M$, Eshetu $M$, Andualem D, Maryo $M$, Legesse $A$. The inventory of camel feed resource and the evaluation of its chemical composition in south-east rangelands of Ethiopia. Vet Med Sci. $2021 \mathrm{Jul} ; 7(4): 1172-84$.

51. Kirui JK, Kotut K, Okemo PO. Efficacy of aqueous plant extract in disinfecting water of different physicochemical properties. Journal of Water and Health. 2015 Sep 1;13(3):848-52.

52. Ng'ang'a MM, Hussain $H$, Chhabra $S$, LangatThoruwa C, Al-Harrasi A, Krohn K, et al. Eucleanal A and $\mathrm{B}$ : Two new napthalene derivatives from Euclea divinorum. Chinese Chemical Letters. 2012 May;23(5):576-8.

53. den Biggelaar C, Mureithi W. Using tree species to treat milk for palatability and preservation. Intermediate Technology Food Chain. 2000;26:6-7.

54. Omara T, Kiprop AK, Kosgei VJ. Albizia coriaria Welw ex Oliver: a review of its ethnobotany, phytochemistry and ethnopharmacology. ADV TRADIT MED (ADTM) [Internet]. 2021 Jul 21 [cited 2022 Feb 26]; $\leq$ URL $>$.

55. Setshego MV, Aremu AO, Mooki O, OtangMbeng W. Natural resources used as folk cosmeceuticals among rural communities in Vhembe district municipality, Limpopo province, South Africa. BMC Complement Med Ther. 2020 Dec;20(1):81.

56. Kaingu CK, Oduma JA, Kanui TI. Practices of Traditional Birth Attendants in Machakos District, Kenya. Journal of Ethnopharmacology. 2011 Sep;137(1):495-502.

57. Keter LK, Mutiso PC. Ethnobotanical studies of medicinal plants used by Traditional Health Practitioners in the management of diabetes in Lower Eastern Province, Kenya. Journal of Ethnopharmacology. 2012 Jan;139(1):74-80.

58. Gakuya DW, Itonga SM, Mbaria JM, Muthee JK, Musau JK. Ethnobotanical survey of biopesticides and other medicinal plants traditionally used in Meru central district of Kenya. Journal of Ethnopharmacology. 2013 Jan;145(2):547-53.

59. Kokwaro JO, Johns T, Kokwaro JO. Luo biological dictionary. Nairobi: East African Educational Publishers; 1998. 264 p.

60. Kama-Kama F, Midiwo J, Nganga J, Maina N, Schiek E, Omosa LK, et al. Selected ethno-medicinal plants from Kenya with in vitro activity against major African livestock pathogens belonging to the " Mycoplasma mycoides cluster." Journal of Ethnopharmacology. 2016 Nov;192:524-34.
61. Kamanja I, Mbaria J, Gathumbi P, Mbaabu M, Lanyasunya A, Gakuya D, et al. Medicinal plants used in the management of sexually transmitted infections by the Samburu Community Kenya. 2015;

62. Johns T, Mahunnah RLA, Sanaya P, Chapman L, Ticktin T. Saponins and phenolic content in plant dietary additives of a traditional subsistence community, the Batemi of Ngorongoro District, Tanzania. Journal of Ethnopharmacology. 1999 Jul;66(1):1-10.

63. Kigen G, Kipkore W, Wanjohi B, Haruki B, Kemboi J. Medicinal plants used by traditional healers in Sangurur, Elgeyo Marakwet County, Kenya. Phcog Res. 2017;9(4):333.

64. Kigen G, Maritim A, Some F, Kibosia J, Rono H, Chepkwony $S$, et al. Ethnopharmacological survey of the medicinal plants used in Tindiret, Nandi County, Kenya. Afr J Trad Compl Alt Med. 2016 Mar $16 ; 13(3): 156$

65. Maroyi A, Cheikhyoussef A. A comparative study of medicinal plants used in rural areas of Namibia and Zimbabwe. 2015; $\leq$ URL>.

66. White F. Flore d'Afrique Centrale (Zaïre Rwanda - Burundi): Ebenaceae. 1987.

67. Gumisiriza $H$, Sesaazi CD, Olet EA, Kembabazi O, Birungi G. Medicinal plants used to treat "African" diseases by the local communities of Bwambara sub-county in Rukungiri District, Western Uganda. Journal of Ethnopharmacology. 2021 Mar;268:113578.

68. Tabuti JRS, Kukunda CB, Waako PJ. Medicinal plants used by traditional medicine practitioners in the treatment of tuberculosis and related ailments in Uganda. Journal of Ethnopharmacology. 2010 Jan;127(1):130-6.

69. Anywar G, Kakudidi E, Byamukama R, Mukonzo $J$, Schubert $A$, Oryem-Origa $H$. Indigenous traditional knowledge of medicinal plants used by herbalists in treating opportunistic infections among people living with HIV/AIDS in Uganda. Journal of Ethnopharmacology. 2020 Jan;246:112205.

70. Namukobe J, Lutaaya A, Asiimwe S, Byamukama R. An Ethnobotanical Study of Medicinal Plants used in the Management of Dermatological Disorders in Buyende and Kayunga Districts, Uganda. EJMP. 2021 Mar 16;15-40.

71. Obakiro SB, Kiprop A, Kowino I, Kigondu E, Odero MP, Omara $T$, et al. Ethnobotany, ethnopharmacology, and phytochemistry of traditional medicinal plants used in the management of symptoms of tuberculosis in East Africa: a systematic review. Trop Med Health. 2020 Dec;48(1):68. 
72. Roba GO. Trees symbolism, conservation and threat in Guji Oromo, Southern Ethiopia. Lu Z, editor. Cogent Social Sciences. 2021 Jan $1 ; 7(1): 1880681$.

73. Lulekal E, Kelbessa E, Bekele T, Yineger H. An ethnobotanical study of medicinal plants in Mana Angetu District, southeastern Ethiopia. J Ethnobiology Ethnomedicine. 2008 Dec;4(1):10.

74. Feyissa T, Asres K, Engidawork E. Renoprotective effects of the crude extract and solvent fractions of the leaves of Euclea divinorum Hierns against gentamicin-induced nephrotoxicity in rats. Journal of Ethnopharmacology. 2013 Feb; 145(3): 758-66.

75. Augustino S, Gillah PR. Medicinal Plants in Urban Districts of Tanzania: Plants, Gender Roles and Sustainable Use. int forest rev. 2005 Mar $1 ; 7(1): 44-58$.

76. Chinsembu KC. Ethnobotanical Study of Plants Used in the Management of HIV/AIDS-Related Diseases in Livingstone, Southern Province, Zambia. Evidence-Based Complementary and Alternative Medicine. 2016;2016:1-14.

77. Saxena M, Saxena J, Nema R, Singh D, Gupta A. Phytochemistry of medicinal plants. Journal of pharmacognosy and phytochemistry. 2013;1(6).

78. Tabuti JRS, Lye KA, Dhillion SS. Traditional herbal drugs of Bulamogi, Uganda: plants, use and administration. Journal of Ethnopharmacology. 2003 Sep;88(1):19-44.

79. Shikwambana N, Mahlo SM. A Survey of Antifungal Activity of Selected South African Plant Species Used for the Treatment of Skin Infections. Natural Product Communications. 2020 May;15(5): 1934578X2092318.

80. Pascaline J, Charles M, George O, Lukhoba C. An inventory of medicinal plants that the people of Nandi use to treat malaria. J Anim Plant Sci. 2011;9:1192-200.

81. Lukwa N, Mutambu S, Makaza N, Molgaard P, Furu $P$. PERCEPTIONS ABOUT MALARIA TRANSMISSION AND CONTROL USING ANTIMALARIA PLANTS IN MOLA, KARIBA, ZIMBABWE. Nigerian Journal of Natural Products and Medicine. 2001 Jan $1 ; 5(1): 4-7$.

82. Hunde D, Asfaw Z, Kelbessa E. Use of traditional medicinal plants by people of 'Boosat'sub district, Central Eastern Ethiopia. Ethiopian Journal of Health Sciences [Internet]. 2006;16(2). $\leq$ URL $>$.

83. Orwa JA, Mwitari PG, Matu EN, Rukunga GM. Traditional healers and the managment of malaria in
Kisumu District, Kenya. E Af Med Jrnl. 2008 Mar $26 ; 84(2): 51-5$.

84. Ruth L, Manani Solomon D. Ethnobotanical survey and propagation of some endangered medicinal plants from south Nandi district of Kenya. J Anim Plant Sci. 2010;8(3):1016-43.

85. Odongo S. Medicinal plants of Chuka community in Tharaka Nithi County, Kenya and some of their selected essential elements [Internet] [Master of Science Thesis]. [Nairobi, Kenya]: Kenyatta University; 2013. $\leq$ URL>.

86. Kokwaro J. Medicinal plants of East Africa. East African Literature Bureau, Nairobi, Kenya; 1976.

87. van Wyk B-E, van Oudtshoorn B, Gericke N. Medicinal plants of South Africa. Pretoria, South Africa: Briza Publications; 1997. 304 p.

88. Smith CA, Phillips EP, Van Hoepen E. Common Names of South African Plants [Internet]. Government Printer, South Africa; 1966. (Botanical Research Institute botanical survey memoir). $\leq \mathrm{URL}>$.

89. Kamau LN, Mbaabu PM, Mbaria JM, Gathumbi PK, Kiama SG. Ethnobotanical survey and threats to medicinal plants traditionally used for the management of human diseases in Nyeri County, Kenya. CellMed. 2016;6(3):21-1.

90. Onyango C, Gakuya L, Mathooko FM, Maina J, Nyaberi $M$, Makobe $M$, et al. Phytochemical studies on herbal plants commonly used for processing and preserving meat and milk. Journal of Applied Biosciences. 2014;73:5942-8.

91. Kokwaro JO. Medicinal plants of East Africa. 3rd ed. Nairobi, Kenya: University of Nairobi Press; 2009. 478 p.

92. Johns $T$, Mhoro EB, Sanaya $P$, Kimanani EK. Herbal remedies of the Batemi of Ngorongoro District, Tanzania: a quantitative appraisal. Econ Bot. 1994 Jan;48(1):90-5.

93. Ngari F, Wanjau R, Njagi E, Gikonyo N. Herbal Materials Used in Management of Oral Conditions in Nairobi, Kenya. Journal of Oral Health \& Community Dentistry. 2014;8(1).

94. Johns T, Kokwaro JO, Kimanani EK. Herbal remedies of the Luo of Siaya District, Kenya: Establishing quantitative criteria for consensus. Econ Bot. 1990 Sep;44(3):369-81.

95. Tadesse M, Demissew S. Plants Used in African Traditional Medicine as Practiced in Ethiopia and Uganda. Botany 2000. 1992; 
96. Balemie K, Kelbessa E, Asfaw Z. Indigenous medicinal plant utilization, management and threats in Fentalle area, Eastern Shewa, Ethiopia. Ethiopian Journal of Biological Sciences. 2004;3(1):37-58.

97. Abate G, Demissew S. Etse Debdabe. In Addis Ababa, Ethiopia: Artistic Printing Press; 1989. p. 123.

98. Gumisiriza $H$, Birungi $G$, Olet EA, Sesaazi CD. Medicinal plant species used by local communities around Queen Elizabeth National Park, Maramagambo Central Forest Reserve and Ihimbo Central Forest Reserve, South western Uganda. Journal of Ethnopharmacology. 2019 Jul;239:111926.

99. Mabona U, Van Vuuren SF. Southern African medicinal plants used to treat skin diseases. South African Journal of Botany. 2013 Jul;87:175-93.

100. Kipkore W, Wanjohi B, Rono H, Kigen G. A study of the medicinal plants used by the Marakwet Community in Kenya. J Ethnobiology Ethnomedicine. 2014 Dec;10(1):24.

101. Okello SV, Nyunja RO, Netondo GW, Onyango JC. Ethnobotanical study of medicinal plants used by sabaots of Mt. Elgon Kenya. Afr J Trad Compl Alt Med [Internet]. 2010 Jul 30 [cited 2022 Feb 26];7(1). $\leq$ URL $>$.

102. Fatuma Some GK. Ethnomedicinal Plants Traditionally Used by the Keiyo Community in Elgeyo Marakwet County, Kenya. J Biodivers Biopros Dev [Internet]. 2014 [cited 2022 Feb 26];01(03). Available from: $\leq U R L>$.

103. Verschaeve L, Van Staden J. Mutagenic and antimutagenic properties of extracts from South African traditional medicinal plants. Journal of Ethnopharmacology. 2008 Oct;119(3):575-87.

104. Muthee JK, Gakuya DW, Mbaria JM, Kareru PG, Mulei CM, Njonge FK. Ethnobotanical study of anthelmintic and other medicinal plants traditionally used in Loitoktok district of Kenya. Journal of Ethnopharmacology. 2011 Apr;135(1):15-21.

105. Njoroge GN, Bussmann RW. Herbal usage and informant consensus in ethnoveterinary management of cattle diseases among the Kikuyus (Central Kenya). Journal of Ethnopharmacology. 2006 Dec;108(3):332-9.

106. Mbabazi I, Wangila P, Krsquo;Owino IO. Comparison of the phytochemical composition of Euclea divinorum Hern Ebenaceae) leaves, tender stems and root bark. Adv J Chem B [Internet]. 2021 Aug [cited 2022 Feb 26];3(3). <DOI>.

107. Mwonjoria J, Ngeranwa J, Githinji C, Wanyonyi A. Antinociceptive effects of dichloromethane extract of Euclea divinorum Lin. Journal of Pharmacognosy and Phytochemistry. $2018 ; 7(6): 1104-7$.

108. Woldemedhin B, Nedi T, Shibeshi W, Sisay M. Evaluation of the diuretic activity of the aqueous and $80 \%$ methanol extracts of the root of Euclea divinorum Hiern (Ebenaceae) in Sprague Dawley rats. Journal of Ethnopharmacology. 2017 Apr;202:114-21.

109. Nyaitondi OD, Wanjau RN, Nyambaka $H$, Hassanali A. Anti-bacterial properties and GC-MS analysis of extracts and essential oils of selected plant product. J Nat Prod Biochem. 2018 Feb $1 ; 16(1): 44-58$.

110. Ngari FW, Gikonyo NK, Wanjau RN, Njagi EM. Safety and antimicrobial properties of Euclea divinorum Hiern, chewing sticks used for management of oral health in Nairobi County, Kenya. J Pharm Biomed Sci. 2013;3(3):1-8.

111. Mothana RA, Lindequist $U$, Gruenert $R$, Bednarski PJ. Studies of the in vitro anticancer, antimicrobial and antioxidant potentials of selected Yemeni medicinal plants from the island Soqotra. BMC Complement Altern Med. 2009 Dec;9(1):7.

112. van der Vijver LM, Gerrritsma K. Naphthoquinones of Euclea and Diospyros species. Phytochemistry. 1974;

113. Cruz-Costa M, Lopes MH, Paul MI, Ferreira MA, Correia-Alves A. Naphthaquinones and triterpenoids of Euclea divinorum. Phytochemistry. 1976;

114. Ng'ang'a MM, Hussain $H$, Chhabra S, LangatThoruwa C, Krohn K, Hussain J, et al. Eucleanal: A New Napthalene Derivative from Euclea divinorum. Natural Product Communications. 2012 Feb;7(2): 1934578X1200700.

115. More G, Tshikalange TE, Lall N, Botha F, Meyer JJM. Antimicrobial activity of medicinal plants against oral microorganisms. Journal of Ethnopharmacology. 2008;119(3):473-7.

116. Obi $\mathrm{CL}$, Potgieter $\mathrm{N}$, Bessong PO, Masebe $\mathrm{T}$, Mathebula $\mathrm{H}$, Molobela $\mathrm{P}$, et al. In vitro antibacterial activity of Venda medicinal plants. South African Journal of Botany. 2003 Jul;69(2):199-203.

117. More G, Tshikalange TE, Lall N, Botha F, Meyer JJM. Antimicrobial activity of medicinal plants against oral microorganisms. Journal of Ethnopharmacology. 2008 Oct;119(3):473-7.

118. Samie A, Tambani T, Harshfield E, Green E, Ramalivhana J, Bessong P. Antifungal activities of selected Venda medicinal plants against Candida albicans, Candida krusei and Cryptococcus neoformans isolated from South African AIDS 
patients. African Journal of Biotechnology. 2010;9(20).

119. Mutuku A. Antimicrobial Activity Of Warburgia ugandensis, Euclea divinorum, Rhus vulgaris, Ocimum gratissimum and Clausena anisata Against Oral Pathogenic Microorganisms [Internet] [Master of Science Thesis]. [Eldoret, Kenya]: University of Eldoret; 2018. $\leq$ URL $>$.

120. Mbabazi I, Wangila $\mathrm{P}$, K'Owino IO. Antimicrobial activity of Euclea divinorum hern (ebenaceae) leaves, tender stems, root bark and an herbal toothpaste formulated from its ethanolic root bark extract. $2020 ; 3(3): 8-16$. $\leq$ URL $>$.

121. Johns T, Faubert GM, Kokwaro JO, Mahunnah RLA, Kimanani EK. Anti-giardial activity of gastrointestinal remedies of the Luo of East Africa. Journal of Ethnopharmacology. 1995 Apr;46(1):1723. $\leq \mathrm{DOI}>$.

122. Mothana $\mathrm{R}, \mathrm{Al}$-Musayeib $\mathrm{N}$, Matheeussen $\mathrm{A}$, Cos $P$, Maes $L$. Assessment of the in Vitro Antiprotozoal and Cytotoxic Potential of 20 Selected Medicinal Plants from the Island of Soqotra. Molecules. 2012 Dec 3;17(12):14349-60. <DOI>.

123. Muthaura CN, Keriko JM, Mutai C, Yenesew A, Gathirwa JW, Irungu BN, et al. Antiplasmodial potential of traditional phytotherapy of some remedies used in treatment of malaria in MeruTharaka Nithi County of Kenya. Journal of Ethnopharmacology. 2015 Dec;175:315-23. $\leq \mathrm{DOI}>$.

124. Twilley D, Langhansová L, Palaniswamy D, Lall N. Evaluation of traditionally used medicinal plants for anticancer, antioxidant, anti-inflammatory and anti-viral (HPV-1) activity. South African Journal of Botany. 2017 Sep;112:494-500. <DOI>.

125. Kaluwa Kaingu C, Oduma JA, Kanui T. Preliminary investigation of contractile activity of Ricinus communis and Euclea divinorum extracts on isolated rabbit uterine strips. Journal of Ethnopharmacology. 2012 Jul;142(2):496-502. $\leq \mathrm{DOI}$.

126. Homer KA, Manji $F$, Beighton D. Inhibition of protease activities of periodontopathic bacteria by extracts of plants used in Kenya as chewing sticks (mswaki). Archives of Oral Biology. 1990;35(6):421-4. <DOI>.

127. Homer KA, Manji $F$, Beighton D. Inhibition of peptidase and glycosidase activities of Porphyromonas gingivalis, Bacteroides intermedius and Treponema denticola by plant extracts. J Clin Periodontol. 1992 May;19(5):305-10. <DOI>.

128. Chapman L, Johns T, Mahunnah RLA. Saponinlike in vitro characteristics of extracts from selected non-nutrient wild plant food additives used by Maasai in meat and milk based soups. Ecology of Food and Nutrition. 1997 Feb;36(1):1-22. <DOI>.

129. JLS, Elgorashi EE, Maes A, Van Gorp U, De Kimpe N, van Staden J, et al. Investigating the safety of plants used in South African traditional medicine: Testing for genotoxicity in the micronucleus and alkaline comet assays. Environ Mol Mutagen. 2003;42(3):144-54. <DOI>.

130. Elgorashi E. Screening of medicinal plants used in South African traditional medicine for genotoxic effects. Toxicology Letters. 2003 Jul 20;143(2):195-207. <DOI>. 